\title{
2. The Role of Government in Future-Proofing Society
}

\author{
The Right Honourable John Key
}

My government has four priorities in its second term (2011-14). The first is to manage the Government's finances responsibly. New Zealand has faced a number of challenges over the past three-and-a-half years, from a recession to the Canterbury earthquakes. The Government has absorbed much of the cost of these events on its balance sheet, so we can cushion New Zealanders from the worst effects. But that money has to be paid back. So we have put a huge amount of effort into making savings and, in particular, into changing some of the long-term term drivers of government spending, so we can get back to surplus over the next few years and start getting our debt down again.

The public sector has played - and continues to play - a very important part in this approach. We have worked with the public sector to identify opportunities for savings, and indeed to identify opportunities for investment, too. We believe people who understand their own services are in the best position to make financial trade-offs and to introduce innovation that genuinely improves public services. As a result, chief executives and senior public servants have been focused on understanding how their organisations work, what drives their costs and how to measure service levels. That approach seems to be working.

Our second priority is to continue building a more competitive and productive economy. We have a very busy program of work going on in a number of areas, to make sure that our regulatory settings are right, that the infrastructure is there to support growth and that resources can flow to their most productive use.

Our third priority is to deliver better public services to New Zealanders within tight fiscal constraints. If you think about it, New Zealanders - and Australians for that matter - have two fundamental interests in their public services. On the one hand, as users they get the benefit of these services, and on the other they also pay for them. For the most part, they do not have much choice either way. They are required to pay through their taxes, and there is often little or no alternative in the provision of public services. So the key challenge facing the Government, and public servants, is to fashion a public sector that works for the people who use its services and is affordable for the taxpayers who fund it.

But the world has changed over the past few years. What seemed affordable, at a pinch, in 2006 or 2007 is now contributing to a structural deficit in the 
Government's accounts. Spending is being reined in to match what the country can afford, but at the same time people's expectations of public services continue to grow. So over the next few years the Government needs good advice and new thinking from the public sector. In fact there has never been a better opportunity for experienced and committed public servants at all levels to contribute to constructive change. It will not be easy but it will be rewarding.

Our fourth and final priority is to support the rebuilding of greater Christchurch, our second-largest city. This will be the biggest economic project ever undertaken in New Zealand. There have already been big implications for the New Zealand Public Service, and that will continue over the course of the rebuild. I will have more to say about Christchurch shortly.

First, I would like to begin with a few brief reflections from the perspective I have on the ninth floor of the Beehive in Wellington. The first is that public policy is hard. So is public management. They are challenging tasks, and much more difficult than commentators, businesspeople, newspaper column writers and the public often think. To my mind, the intellectual and practical challenges of the public service are what attract so many capable and motivated New Zealanders to work in it.

Public policy and management are also hugely important tasks. Governments always need good advice, they need a sound system of financial management, they need skilled people to run what are often large organisations, and they need to know how their decisions will affect society and the economy.

As prime minister, I find the most difficult, hard-to-tackle issues of public policy inevitably end up passing across my desk. In working through those issues, I rely heavily on the advice and judgment of public servants. It is crucial that ministers know all the sides of a particular issue, have all the relevant information and fully understand the implications of different courses of action. Since becoming prime minister in late 2008, I have been impressed by the professionalism and competence of public servants in my own departments and across the public sector as a whole. The approach of my government has been to respect people's professional skills and to back public servants who want to get on and make New Zealand a better place.

As just one example, we have reintroduced the practice of having officials regularly attend cabinet committee meetings. That is for two reasons. We want to get advice from the people who have the greatest knowledge of particular issues. And we actually think it is good for officials to see where ministers agree and disagree, what they feel comfortable with and what drives their consideration of a particular issue. 
We also respect the neutrality of the public sector. It is one of the great strengths of the New Zealand public management system. But while it is important for governments of all stripes to respect the political neutrality of the public sector, it is equally important for public servants to respect the political mandate of the Government. So the first thing I would say to you is that advice from the public service is highly valued and it is always considered carefully.

Yet that advice can only go so far, for government is not a technocratic exercise. In the end, the biggest, most fundamental decisions governments are called on to make cannot be calculated in a spreadsheet. And in a lot of areas, the most thorough policy analysis does not lead to an inevitable conclusion; it simply highlights the fundamental judgments that have to be made around concepts like fairness, opportunity and the balance between individual and social responsibility. That is why we have an elected government - so that politicians make those sorts of judgments and are accountable to the people of New Zealand, or of Australia, for doing so.

Governments also have to bring things to a head. The public and the media can debate issues forever but, in the end, the government has to cut through them and make a decision, which will invariably please some people and disappoint others. In some cases that decision is to do something and in other cases it is to not do something. Either way, a decision has been made. In making those decisions, my government has been very pragmatic.

We are guided by the values and principles of the party we represent in Parliament, but we are also focused on what is sensible and what is possible. Partly, that is the nature of the political system in New Zealand. It is sometimes said that politics is about convincing 50 per cent of the population plus one, and that has never been truer than under our multimember proportional electoral (MMP) system. But, in any event, government is a practical business. You do not start with a blank sheet of paper; you start with the country as it is. And by making a series of sensible decisions, which build on each other and which are signalled well in advance, and by taking more people with you as you go, you can effect real and durable change. That has certainly been our experience in New Zealand.

I also believe in keeping my word with the electorate. One of the characteristics of this government has been that we have been consistent and upfront with New Zealanders about what we are doing and why. We campaigned openly on a very clear program and that is what we are implementing. At each election we have sought a mandate for new policies we want to put in place. And we have made clear assurances about the policies we will maintain. 
Trust is fundamental to the relationship between politicians and voters, just as it is fundamental to the relationship between politicians and public servants. Some governments have really surprised people on coming into office but that has never worked out very well. So whether people like us or not, they know what to expect from us.

Looking ahead, good public sector management will be critical in the years to come. Around the world, governments are facing persistent budget deficits and a growing debt burden they will be struggling with for years. Yet their citizens are rightly expecting the sort of twenty-first-century services they get from private sector industries competing aggressively for their business, like banks and airlines. The combination of these two forces will place governments and public servants around the world under constant pressure to deliver better services for less money.

New Zealand is no different. We are in a new environment that will persist for at least the next decade. The mid 2000s were characterised by the idea that big increases in government spending, dispensed across a whole range of areas and in a relatively untargeted way, could transform society. According to this view, the sheer weight of spending would eventually prevail; however, that particular experiment ran out of money in 2008 with little genuinely transformational to show for it.

Public management in the foreseeable future will be focused on determining which public services and income-support measures are the most effective, and working out how to provide those within a tightly constrained budget. It will be focused on presenting a service that is far more coordinated than it is now. New Zealanders do not live in government departments and they do not always understand the demarcations between different arms of government. To them, the government is one big organisation that should be able to help them when they need it. And they are right - it should.

Technology will make that goal more achievable. It is important that new technology is not just tacked onto current business practices. Rather, it should facilitate change in those business practices. And public management will be focused on getting results.

We have been very clear with the public service about what we want it to focus on. In March 2012, I announced a set of results I want to see achieved over the next five years. They are not everything the Government is doing, or everything the Government thinks is important. But they are results for which I want to see real progress. They involve tackling some of the longstanding, difficult issues we have in this country. And they tend to fall between or across the responsibilities of individual government departments, which is part of the reason they are 
difficult to tackle. Many readers, especially New Zealanders, will be familiar with these 10 results and with the targets attached to each of them. The targets are quite ambitious. Some of them are, for example

- to reduce by 30 per cent the number of people on a working-age benefit for more than 12 months

- to reduce the incidence of rheumatic fever by two-thirds

- to reduce the violent crime rate by 20 per cent.

I make no apologies for having high expectations. I do not want targets that are easy to reach. I want people to have to stretch, and feel uncomfortable, and change the way they have always done things, in order to reach the targets. And the Government will back them in doing that.

I have appointed a minister to lead each of the 10 results and a public service chief executive has been made accountable for demonstrating real progress against his or her result. We are giving the public sector the flexibility, the encouragement and the mandate to make real change.

I certainly do not underestimate the challenges involved in this new approach. The targets are difficult, and to reach them means changing the way the public sector functions. In the past it has almost operated as a loose federation of separate agencies. In the future it will have to operate much more as an integrated system. I am delighted to say the leadership of the public service has been very supportive of this new approach. At times during the process of developing the results program they were at least as ambitious as ministers were. That is a great sign that things needed to change and that in fact they will change.

I would like now to discuss the Canterbury earthquakes, our response to them and the lessons we have learnt from that response. Governments on both sides of the Tasman have been tested by disasters quite frequently in recent years. Australia has experienced the Victorian bushfires and the Queensland floods. In New Zealand, we have had earthquakes.

The first Canterbury earthquake struck in the early hours of Saturday, 4 September 2010. Damage and liquefaction were widespread. But when we look back at that event with the benefit of hindsight, it's clear that in many ways we were lucky. We were lucky the earthquake happened at $4 \mathrm{am}$, when most people were not out and about. We were lucky that while people were injured, no-one lost their life. And we were lucky for another reason that we could not have known at the time: that we would be practised and ready when a far more destructive earthquake struck a few months later.

On 22 February 2011, 185 people were killed in one of this country's worst natural disasters. It is the kind of event governments spend years preparing 
for, but in truth you never really know you are ready until the day comes. In Canterbury, we saw the benefits of good preparation and planning. The immediate response was well coordinated, with clear leadership structures that were widely understood. People knew what their roles were and set about getting things done.

Beyond the initial emergency response, the Government faced a huge number of challenges. There were accommodation needs; questions over whether employers could keep their businesses open; and major infrastructure needs like water, wastewater, electricity and roads. On the ground, the public sector was forced to find new ways to deliver services. I am pleased to say that in adversity, the public sector really stepped up to the plate. A healthy amount of freedom was given to frontline staff to get things done-and they did.

The Government also moved rapidly to address the many policy issues we faced. For example, we had a support package for employers and employees, including subsidies, available less than a week after the earthquake. It was crucial to keep the lines of communication open between employers and employees in order to preserve jobs, so we designed the package quickly and erred on the side of generosity rather than having stringent rules.

Another example was the Government's residential red zone offer to property owners. This involved the Government offering to purchase properties on the worst affected land at their current rating valuation. The scheme enabled homeowners to move on with their lives quickly. There were many other policies developed in those conditions and sometimes we pushed people very hard. It will not surprise you that there were some robust conversations at timesbecause, to some people, it appeared things could not be done as rapidly as we wished. But we got there. We got there because people were innovative and flexible.

It is now 17 months since the destructive earthquake on 22 February and as a government we have been examining the lessons we can take from it, particularly around how the public sector operates. The kind of innovation we saw is what we would like to see from the public sector in ordinary times - not just in times of disaster. Collaboration between agencies was a feature, and this extended to involving the private sector, non-governmental organisations (NGOs) and representatives of the public alongside government. There was greater sharing of information between agencies, and more sharing of resources. People were agile and showed initiative. They came up with solutions that focused firmly on what the people of Canterbury actually needed. The challenge now is to take that innovative approach and apply it to the public sector when we are not in a time of crisis - and I think the public sector is open to that. 
The final point I would like to make about Canterbury is that the earthquake response has taken us into new territory as a government. We have learned some valuable lessons from overseas disaster recoveries, but have very much taken decisions that fit the New Zealand context. Our response has included appointing a minister, Gerry Brownlee, to specifically oversee the recovery. We have passed legislation to give additional powers to central government and we set up a new government agency, the Canterbury Earthquake Recovery Authority, or CERA, to provide leadership and coordination. CERA has wide powers, which were the source of some contention when we passed the necessary legislation. We were conscious to strike the right balance between getting things done and having adequate checks and balances around the organisation.

I believe we got that balance right. There is still a lot to be done in Canterbury but we are making good progress. 
This text taken from Future-Proofing the State: Managing Risks, Responding to Crises and Building Resilience, edited by Jonathan Boston, John Wanna, Vic Lipski and Justin Pritchard, published May 2014 by ANU Press, The Australian National University, Canberra, Australia. 